УДК 373.3.015.31:172.15:379.822

DOI:

Олена Квас, доктор педагогічних наук,професор кафедри загальної педагогіки та дошкільної освіти Дрогобицького державного педагогічного університету імені Івана Франка Сузанна Волошин, аспірант кафедри педагогіки та методики початкової освіти Дрогобицького державного педагогічного університету імені Івана Франка

\title{
ФОРМУВАННЯ ПАТРІОТИЧНОЇ ВИХОВАНОСТІ УЧНІВ ПОЧАТКОВОЇ ШКОЛИ ЗАСОБАМИ МУЗЕЙНОЇ ПЕДАГОГІКИ
}

У статті висвітлено проблему формування патріотичної вихованості учнів початкової школи засобами музейної педагогіки. Акцентовано увагу на таких організаційно-педагогічних умовах патріотичного виховання молодших школярів засобами музейної педагогіки, як розвиток музейно-педагогічної компетентності вчителя; забезпечення партнерської взаємодії школи і музею; впровадження засобів музейної педагогіки в практику освітньої роботи початкової школи. Розкрито стан патріотичного виховання молодших школярів у практичі початкової школи, визначено та обтрунтовано критерії, показники та рівні сформованості патріотичноі вихованості молодших школярів, проаналізовано діагностичне дослідження шляхом кількісного та якісного аналізу отриманих результатів.

Ключові слова: патріотична вихованість; музейна педагогіка; учні початкової школи.

Jim. 8.

\author{
Olena Kvas, Doctor of Sciences (Pedagogy), Professor of the \\ General Pedagogy and Preschool Education Department \\ Drohobych Ivan Franko State Pedagogical University \\ Susanna Voloshyn, Postgraduate Student of the \\ Pedagogy and Methodology of Preschool Education Department \\ Drohobych Ivan Franko State Pedagogical University
}

\section{THE FORMATION OF PATRIOTIC EDUCATION OF PUPILS OF THE PRIMARY SCHOOL BY MEANS OF MUSEUM PEDAGOGY}

In the article the problem of formation of patriotic education the pupils of the primary school by means of the museum pedagogy was elucidated. The attention is accentuated on such organizational and pedagogical conditions of patriotic education of junior pupils by means of the museum pedagogy, as the development of museum-pedagogical competence by the teacher, providing the partner interaction between school and museum; the introduction of the means of museum pedagogy in the practice of educational work of the primary school. The state of patriotic education of junior pupils in elementary school was disclosed, an attention on the analysis of the calendar plans of the teachers' educational and training work was accentuated, attention on the results of the questioning of the teachers regarding the underestimating of the museum environment in realization of patriotic education of junior schoolchildren was paid. The criterias and levels of formation of patriotic education of younger schoolchildren are determined and substantiated, according to which indicators were developed, namely: knowledge of the pedigree, knowledge about Small and Great Motherland, understanding of elementary concepts of patriotic content; patriotic feelings for the Little Motherland, the value orientations of younger schoolchildren, their relation to their native land, country, people; patriotic desires and motives, active participation in socially useful activities, manifestation of patriotic qualities in actions and acts. The diagnostic research by means of quantitative and qualitative analysis of the obtained results was analyzed.

Keywords: the patriotic education; the museum pedagogy; the pupils of the primary school.

П остановка проблеми. Сьогодні у зв'язку із обставинами, які склалися в українській державі, почуття патріотизму та активної громадянської позиції набуває усе більшої актуальності у молодого покоління, зокрема й учнів початкової школи. Особливу роль у ході обороноздатності України відіграє організація збирання та поширення інформації про героїчні вчинки українських військовослужбовців, бійців добровольчих батальйонів, волонтерів та інших громадян. 3 цією метою виникає необхідність переосмислення зробленого і здійснення системних заходів, спрямованих на посилення патріотичного виховання учнів початкової школи, найважливішим пріоритетом якого $є$ формування ціннісного ставлення особистості до українського народу, Батьківщини, нації, отже формування у молодших школярів патріотичної вихованості.

У процесі державотворення сьогодні потрібна 


\section{ФОРМУВАННЯ ПАТРІОТИЧНОЇ ВИХОВАНОСТІ УЧНІВ ПОЧАТКОВОЇ ШКОЛИ ЗАСОБАМИМУЗЕЙНӦ̈ ПЕДАГОГІКИ}

ефективна система патріотичного виховання, змістовим компонентом якої є духовно-культурна спадщина народу України. Оскільки в основу національної системи патріотичного виховання покладено національну ідею, форми і методи базуються на народних традиціях, кращих надбаннях національної та світової педагогіки й психології. Сьогодні сформоване соціальне замовлення на ефективні технології, у процесі використання формуватимуться патріотичні почуття, любов до свого народу, глибоке розуміння громадянського обов'язку, готовність відстоювати державні інтереси Батьківщини [1;8].

Проблема патріотизму знайшла своє відображення у вітчизняних та зарубіжних доробках. Більшістю філософів, педагогів, психологів минулого(Я. Коменським, К. Ушинським, В. Сухомлинським, М. Стельмаховичем та ін.) відстояно думку про те, що в результаті активної, пізнавальної, альтруїстичної, громадсько-корисної діяльності зміцнюється формування патріотизму як генералізуючого новоутворення молодшого шкільного віку - найбільш сензитивного для становлення етнічної свідомості періоду й виховання позитивних рис особистості, так як у дитини створюються уявлення про Малуі Велику Батьківщину, формуються поняття патріотизму "родина" - “домівка" - "місто" - “регіон” "країна".

Оскільки на нинішньому етапі творення Нової української школи діти молодшого шкільного віку утверджуються в нових цікавих сферах діяльності, в тому числі музеєзнавчої, особливої актуальності набуває проблема оновлення змісту початкової освіти, її модернізація засобами музейної педагогіки. Тому завдання вчителя - зберегти для майбутнього ті предковічні здобутки народу, які лежать у підвалинах його існування, і передати наступному поколінню.

Аналіз основних досліджень і публікацій. Аналіз науково-педагогічної та психологометодичної літератури дозволяє стверджувати, що проблема змісту освіти у контексті патріотичного виховання знаходить своє відображення у наукових доробках сучасних науковців. Теоретико-технологічні засади патріотичного виховання у площині особистісно зорієнтованого підходу розкривають сучасні науковці I. Бех [1], О.Сухомлинська [8] та ін. Своє відображення знаходить і проблема змісту освіти у контексті різних аспектів музейної педагогіки. Так, загальні поняття, пов'язані з музеологією, їі сугністю, завданням, проаналізовані М. Ругинським [7], В. Петранівським, О. Стецюком [6]. Проблему формування нормативно-правової бази діяльності музеїв при навчальних закладах України, їх оптимальні моделі висвітлено Л. Гайдою [3]. Науковцями Т. Вайнгбергом та С. Хавіною [2] розкрито музейну педагогіку як перспективний напрям у сучасній системі національної освіти. Роль навчального середовища в реалізації музейних педагогічних програм і проектів досліджено О. Карамановим [5]. Формування соціально-культурної компетенції учнів засобами вивчення скарбів культури і старовини українського народу подано у методичному посібнику А. Дульської [4].

Сьогодні є відсутніми наукові дослідження експериментального виду, в яких патріотичне виховання молодших школярів розкрито засобами музейної педагогіки. Тому мета статті висвітлити експериментальну модель патріотичного виховання учнів початкової школи засобами музейної педагогіки.

Виклад основного матеріалу. У процесі дослідження ми акцентували увагу на таких організаційно-педагогічних умовах патріотичного виховання молодших школярів засобами музейної педагогіки, як розвиток музейно-педагогічної компетентності вчителя; забезпечення партнерської взаємодії школи і музею; впровадження засобів музейної педагогіки в практику освітньої роботи початкової школи. Розкриваючи стан патріотичного виховання молодших школярів у практиці початкової школи, нами здійснено аналіз календарних планів навчальної та виховної роботи вчителів та навчально-методичного забезпечення процесу патріотичного виховання.

На етапі констатувального експерименту визначено та обгрунтовано критерії, показники та рівні сформованості патріотичної вихованості молодших школярів, проведено діагностичне дослідження, здійснено кількісний та якісний аналіз отриманих результатів. 3'ясовано, що формування національної свідомості у початковій школі відбувається через навчальні предмети відповідно до нового Державного стандарту початкової освіти, різноманітні заходи виховної і позакласної роботи.

Досліджено, що у класах оформлені куточки державної символіки; традиційними заходами $є$ відзначення днів Збройних Сил України, Українського козацтва, Соборності і Свободи України, Дня української писемності і мови, Шевченківські дні. Мають місце й тематичні уроки та виховні години, уроки мужності, бесіди, виставки дитячої зображувальної творчості, святкові концерти, козацькі забави, зустрічі 3 цікавими земляками-патріотами. У ході аналізу 


\section{ФОРМУВАННЯ ПАТРІОТИЧНОЇ ВИХОВАНОСТІ УЧНІВ ПОЧАТКОВОЇ ШКОЛИ ЗАСОБАМИМУЗЕЙНОЇПЕДАГОГІКИ}

нормативних документів та програм 3 патріотичного виховання у початковій школі виявлено, що організація патріотичного виховання базується на засадах Стратегї патріотичного виховання дітей та молоді та Програмі українського патріотичного виховання дітей та учнівської молоді.

Проведене анкетування вчителів початкових класів щодо застосування у процес освітньої роботи засобів музейної педагогіки засвідчило про загальне ставлення педагогів до питань досліджуваної проблеми, її змісту. Результати анкетування показали, що вчителі усвідомлюють важливість патріотичного виховання молодших школярів, однак недооцінюють уздійсненні цього процесу освітніх можливостей музейного середовища.

Нами було розроблено результати діагностування молодших школярів, в основі якого була покладена структура їх патріотичної вихованості із використанням наступних методів дослідження: опитування, бесіда, анкетування, метод незакінчених речень, метод розв’язання проблемних ситуацій, методика М. Рокича “Ціннісні орієнтації'.

Для об'єктивного виявлення рівнів патріотичної вихованості учнів початкової школи виділено три складові компоненти: пізнавально-когнітивний, емоційно-ціннісний та поведінковий, відповідно до яких розроблено показники рівнів патріотичної вихованості молодших школярів.

Критерієм оцінки рівня пізнавальнокогнітивного компонента виділено сформованість патріотичних знань із показниками: знання родоводу, знання про Малу і Велику Батьківщину, розуміння елементарних понять патріотичного змісту. Критерієм оцінки рівня емоційноціннісного компонента патріотичної вихованості виокремлено вираженість патріотичних почуттів та ціннісного сприйняття рідного краю, держави, ознак нації із показниками: патріотичні почуття до “малої” Батьківщини, ціннісні орієнтації молодших школярів, ставлення до рідного краю, країни, народу. Критерієм оцінки рівня поведінкового компонента подано прояв патріотичної поведінки із показниками: патріотичні прагнення та мотиви, активна участь у суспільно корисній та культуротворчій діяльності, прояв патріотичних якостей у діях і вчинках.

Окреслені структурні компоненти, критерії та показники патріотичної вихованості учнів початкової школи дали змогу простудіювати три рівні сформованості їх патріотичної вихованості та оцінити їх.

Встановлено, що високий рівень характеризується повнотою знань про родинні зв'язки, про історію, культуру міста, країни. Учні орієнтуються у родовідних лініях до третього покоління, розуміють символіку міста, мають знання про певні історичні події, про цікаві місця в Україні, знають про національні свята і традиції, пов'язані 3 ними, пояснюють основні поняття патріотичного змісту. У них сформоване стійке позитивне ставлення до рідного краю, до Батьківщини, до народу; виражене почуття прихильності, любові, інтересу до малої Батьківщини, країни, виявляється ціннісне ставлення до природи, культури та традицій. Участь у патріотично спрямованій діяльності відзначається активністю, ініціативністю, вчинки та оцінки регулюються моральними засадами.

Визначено, що середній рівень характеризується недостатньою повнотою патріотичних знань молодших школярів про сімейний родовід, історію міста, країни, народні традиції, недостатнім розумінням понять патріотичного змісту. Учні виявляють загальне позитивне ставлення до “малоі” Батьківщини, до країни, інтерес до історії, культури. Однак ціннісне ставлення до природи, народних традицій сформовані недостатньо. Учні обізнані із моральними нормами поведінки, але мотивація їх дотримання нестійка, патріотичні якості виявляються ситуативно. Участь у патріотично спрямованій діяльності не відзначається особливою активністю.

3'ясовано, що низький рівень характеризується обмеженістю знань молодших школярів про членів сім’ї, про рідний край, національні історію, традиції, культуру, неточністю розуміння елементарних понять патріотичного змісту. У ставленні до “малої” Батьківщини простежуються прояви певного негативізму або байдужості. Національні культура, традиції, історія, почуття гордості за Батьківщину не є ціннісними і значимими. Властива інертність або відмова щодо участі у суспільно корисній праці, у заходах патріотичної спрямованості. Дії та вчинки рідко регулюються моральними засадами.

Охарактеризовані критерії та показники патріотичної вихованості молодших школярів були покладені в основу діагностики, спрямованої на виявлення належності учнів до означених рівнів за кількісними та якісними параметрами. Нами досліджено, що патріотичне виховання особистості $€$ взаємопов'язаним процесом накопичення патріотичних знань і уявлень, формування патріотичних почуттів, цінностей, переконань, реалізації засвоєних і емоційно пережитих знань в діях та поведінці.

На констатувальному етапі експерименту було 
виокремлено критерії патріотичної вихованості молодших школярів:

- сформованість патріотичних знань із показниками: знання родоводу; знання про “малу” та “велику" Батьківщину; розуміння елементарних понять патріотичного змісту;

- вираженість патріотичних почуттів та ціннісного сприйняття рідного краю, держави, ознак нації з показниками: патріотичні почуття до “малої” Батьківщини; ціннісні орієнтації молодших школярів; ставлення до рідного краю, країни, народу;

- прояв патріотичної поведінки із показниками: патріотичні прагнення та мотиви; активність у суспільно корисній праці, культуротворчій діяльності; прояв патріотичних якостей у діях та вчинках.

Відповідно до рівня сформованості компонентів визначено три рівні (високий, середній, низький) сформованості патріотичної вихованості молодших школярів. Такий стан зумовив розробку організаційно-педагогічних умов патріотичного виховання молодших школярів засобами музейної педагогіки: розвиток музейно-педагогічної компетентності вчителя; забезпечення партнерської взаємодії школи і музею; впровадження засобів музейної педагогіки в практику освітньої роботи початкової школи.

Варто зауважити, що освітній процес в експериментальних класах був нами організований 3 урахуванням не лише визначених нами організаційно-педагогічних умов, а й розробленої нами експериментальної моделі патріотичного виховання учнів початкової школи засобами музейної педагогіки. У контрольних класах освітня робота проводилася за шкільним планом.

Експериментальна модель патріотичного виховання учнів початкової школи включала два етапи: підготовчий (пропедевтична робота 3 вчителями); організаційно-корекційний (партнерська взаємодія; предметно-розвивальне середовище музею; оригінальні експонати; музейні предмети; навколомузейний простір; будівля музею).

Методи та форми організації освітньої роботи застосовувалися відповідно до реалізації означених етапів.

На першому - підготовчому етапі реалізовувалась педагогічна умова - розвиток музейно-педагогічної компетентності вчителя. Для підвищення майстерності, професіоналізму вчителів використовувалися різноманітні форми роботи: лекції (“Музейна педагогіка: теоретичні та практичні аспекти”, “Музейна педагогіка як засіб патріотичного виховання”), бесіди, семінари (“Патріотичне виховання молодших школярів”), круглі столи (“Особливості патріотичної вихованості молодших школярів”, “Музейна педагогіка як сучасний освітній ресурс"), майстер-класи (“Я поведу тебе в музей”), педагогічні практикуми (“Навчаємо в музеї”).

На другому-організаційно-корекційному етапі - реалізовувалась педагогічна умова забезпечення партнерської взаємодії школи і музею. Проведено круглий стіл “Музей в освітньому просторі: діалог та взаємодія”, під час якого педагоги та музейні працівники обговорювали умови налагодження системної співпраці, висловлювали свої очікування від взаємодії, узгоджували найбільш ефективні форми співпраці.

Організаційно-корекційний етап експериментального дослідження також був спрямований на роботу з молодшими школярами, а саме на реалізацію педагогічної умови - впровадження засобів музейної педагогіки в практику освітньої роботи початкової школи. Із учнями ми використовували такі інтерактивні технології, як музейні уроки (“Секрети народних орнаментів”, “Ткацтво. Михайло Білас"), тематичні музейні заняття (“Дрогобича славні імена”, “Радість зимових свят”, “Великдень в музеї”, “Відкриваємо скриню”, “Народні візерунки”, “Дерево роду”, "Козацькому роду нема переводу”, “Зимівля птахів”, “У світі Франкових звірів”), урокитеатралізації, майстер-класи ("Виготовлення різдвяного павука”, “Виготовлення писанки”, “Великодня світлиця”, “Наші обереги”), літературні читання у музеї, виставки (“Старий Дрогобич на листівках та світлинах”, “Ангели України”), екскурсії (тематичні (“Народний одяг”), інтерактивні (“У гості до Франка", "В гостях у лісових друзів”), віртуальні подорожі, дослідницькі міні-проекти (“Славетні дрогобичани”, “Їхніми іменами названі вулиці”, “Рідне місто”, “Моя вулиця”, “Абетка мого міста").

Задля реалізації цієї педагогічної умови було використано низку методів: словесні (розповідь, пояснення, бесіда), наочні (ілюстрація, демонстрація, відеометод), практичні (творчі завдання), методи народної педагогіки, метод прикладу, “метод занурення" та ігрові методи і прийоми (дидактичні, ситуаційно-рольові, сюжетно-рольові, рухливі ігри, ігри-бесіди, ігримандрівки, ігрові вправи, ігрові завдання) та прийом театралізації.

Реалізовані у ході формувального етапу експериментального дослідження організаційнопедагогічні умови були у діалектичному зв'язку та доповнювали одна одну. 


\section{ФОРМУВАННЯ ПАТРІОТИЧНОЇ ВИХОВАНОСТІ УЧНІВ ПОЧАТКОВОЇ ШКОЛИ ЗАСОБАМИ МУЗЕЙНОӤ ПЕДАГОГКИ}

Аналіз результатів експериментального дослідження дозволив визначити на прикінцевому етапі вирішення завдань шляхом визначення динаміки змін, що відбулися у процесі патріотичного виховання молодших школярів засобами музейної педагогіки та проведенні зіставної характеристики сформованості рівнів патріотичної вихованості в експериментальній та контрольній групах після формувального експерименту. Для реалізації поставлених завдань проведено контрольний зріз на основі завдань, аналогічних тим, що застосовувалися на констатувальному етапі дослідження.

Отже, доведено, що реалізація організаційнометодичної моделі як сукупності підходів та принципів організації освітнього процесу, забезпечення відповідних педагогічних умов сприяє ефективному підвищенню рівня сформованості патріотичної вихованості молодших школярів.

\section{ЛІТЕРАТУРА}

1. Бех І. Д. Виховання особистості / І. Д. Бех. - К.: Либідь, 2003. - Кн. 1: Особистісно зорієнтований підхід: теоретико-технологічні засади. -278 с.

2. Вайнберг Т. Б. Музейна педагогіка перспективний напрям у сучасній системі національної освіти / Т. Б. Вайнберг, С. Я. Хавіна // Вивчаємо українську мову та літературу. Позакласна робота. - 2014. - № 2 (02). - С. 2 - 7 .

3. Гайда Л. До питання підготовки навчальнометодичного посібника "Музеєзнавство у закладах освіти” / Л. Гайда // Український музей при навчальному закладі: історія і сучасність. Матеріали обласної науково-методичної конференції. - Кіровоград: Видавництво Кіровоградського обласного інституту післядипломної педагогічної освіти імені Василя Сухомлинського, 2008. - С. 118 - 119.

4. Дульська А. А. Формування соціальнокультурної компетенції учнів МНВК засобами вивчення скарбів культури і старовини українського народу: методичний посібник / А. Дульська. Кам'янець - Подільський, 2014. - 68 с.

5. Караманов О. В. Роль навчального середовища в реалізації музейних педагогічних програм і проектів / О. В. Караманов // Пост. методика. - 2013. - № 3. - С. 41 - 44.

6. Петранівський В. Л. Туристичне краєзнавство: навч. посіб. /В.Л. Петранівський, М. Й. Рутинський. - К., 2008. - 2-ге вид., виправл. - 575 с.

7.РугинськийМ.Й.Музеєзнавство/М.Й.Рутинський, О. В. Стецюк: навч. посіб. - К.: Знання, 2008. $428 \mathrm{c}$.
8. Сухомлинська О. В. Патріотизм як цінність: погляд на історію і сьогодення / О.В. Сухомлинська // Шлях освіти. - 2010. - № 2. - С. 10 - 14.

\section{REFERENCES}

1. Bekh, I. D. (2003). Vykhovannia osobystosti [Education of the person]. Kyiv, p. 278. [in Ukrainian].

2. Vainberh, T. B. \& Khavina, S.Ya. (2014). Muzeina pedahohika - perspektyvnyi napriam u suchasnii systemi natsionalnoi osvity [Museum education - a promising trend in modern system of national education]. Study Ukrainian and literature. Extracurricular work. Vol. 2 (02), pp.2 - 7. [in Ukrainian].

3. Haida, L. (2008). Do pytannia pidhotovky navchalno-metodychnoho posibnyka "Muzeieznavstvo u zakladakh osvity" [Prior to the preparation of a manual "Museology in educational institutions"]. Materialy oblasnoi naukovo-metodychnoi konferentsii "Ukrainskyi muzei pry navchalnomu zakladi: istoriia i suchasnist" - Proceedings of regional scientifically methodical conference. "Ukrainian museum at educational establishment: history and contemporaneity" (pp.118-119). Kirovohrad: Kirovohrad regional institute of pedagogical formation of the name of Vasyl Suhomlinskyi. [in Ukrainian].

4. Dulska, A. A. (2014). Formuvannia sotsialnokulturnoi kompetentsii uchniv MNVK zasobamy vyvchennia skarbiv kultury $i$ starovyny ukrainskoho narodu [Forming of sociocultural competense of students MNVK of by facilities of study of treasures of culture and antiquity of the Ukrainian people]. Kamianets - Podolsk, p. 68. [in Ukrainian].

5. Karamanov, O. V. (2013). Rol navchalnoho seredovyshcha $v$ realizatsii muzeinykh pedahohichnykh prohram i proektiv [A role of educational en vironment is in realization of themuseum pedagogical programs and projects]. Post. Methodology, no. 3, pp. 41 - 44. [in Ukrainian].

6. Petranivskyi, V. L. \& Rutynskyi, M. I. (2008). Turystychne kraieznavstvo [Tourist study of a particular region]. Kyiv, p. 575. [in Ukrainian].

7. Rutynskyi, M. Y. \& Stetsiuk, O. V. (2008). Muzeieznavstvo [Muzeeznavstvo]. Kyiv: Knowledge, p. 428. [in Ukrainian].

8. Cukhomlynska, O. V. (2010). Patriotyzm yak tsinnist: pohliad na istoriiu i sohodennia [Patriotism as a value: a view of history and present]. Education path, no. 2, pp. 10 - 14. [in Ukrainian].

Стаття надійшла до редакції 09.10.2018 